\title{
Editorial
}

\section{Democracy in Retreat: Two Examples of Numeric Comparative Law and Governance}

Does democracy has any chance to win against non-democratic regimes in the 21th century? The current behaviours of several Presidents and Prime Ministers of so-called democratic countries give reasons to worry. Leaders like Donald Trump, Recep Tayyip Erdogan, Viktor Orban, Andrzej Duda, and now Boris Johnson, push democracy over the edge. ${ }^{1}$ The Russian and Chinese efficiency in securing long-lasting power to one and the same political party, or even to one and the same leader, seems to increasingly inspire the strategies of political leaders in America and Europe. Boris Johnson's recent 'coup', 2 the planned prorogation of Parliament for five weeks in order to quickly realise the Brexit without being hampered by parliamentary discussions, only represents the top

1 See S. Bauer, 2018. 'Democracy on the Edge'. The New Federalist, January 4. Retrieved 4 September 2019, https://www.thenewfederalist.eu/democracy-on-the-edge, with further references; A. Renwick, 2019. 'Boris Johnson's unprecedented decision is indeed a threat to our democracy'. The Telegraph (telegraph.co.uk), August 28. Retrieved 4 September 2019, https://www.telegraph.co.uk/politics/2019/08/28/boris-johnsons-unprecedented-decision -indeed-threat-democracy/.

2 'Stop the Coup' is the motto of several public protests against Johnson's plan to prorogue Parliament, which took place in the last week of August and the first week of September 2019 both in the UK and abroad. See L. Waters, 2019. 'Boris Johnson drowned out by protesters shouting 'Stop the Coup' outside Downing Street'. Indy10o, September 3. Retrieved 4 September 2019, https://www.indy1oo.com/article/boris-johnson-speech-brexit-chanting-downing-street -coup-no-deal-vote-9089486. See also P. Cockburn, 2019. 'I recognise Boris Johnson's coup for what it is because I've seen this before - in Turkey'. The Independent (independent.co.uk), August 30. Retrieved 4September 2019, https://www.independent.co.uk/voices/boris-johnson -prorogation-parliament-erdogan-democracy-turkey-ago86011.html. 
of the iceberg. The global iceberg seems to be slowly shifting democracy towards authoritarianism. ${ }^{3}$

Comparative overviews of this worrying global phenomenon are provided yearly both in the 'Freedom in the World' reports, authored by the non-profit and non-partisan US think tank Freedom House, ${ }^{4}$ and in the Economist Intelligence Unit's (EIU) Democracy Index. ${ }^{5}$ The Freedom in the World 2019 report, entitled 'Democracy in Retreat', ${ }^{6}$ considers the legal and political developments of 2018 in 209 countries and territories around the globe. It divides the countries in three groups: free, partly free, and not free. Expectedly, only a minority of countries (44\%) are categorized as "free", among which Australia, Canada, Japan, the United States, and the vast majority of European countries (including Poland). Within the European Union, only Hungary is "partly free", according to the report.

An appalling picture emerges from the Freedom in the World reports over the last decade. Since 2006, a total of 116 countries have seen a decline in democratic freedoms, while only 63 countries have experienced growth. ${ }^{7}$ The 2019 report confirms this trend. It downgrades the status of four countries (Hungary, Nicaragua, Serbia, and Uganda) in comparison to 2018, while it upgrades it for only one country (Zimbabwe, from "not free" to "partly free"). ${ }^{8}$

Democracy clearly seems to be in retreat also according to the EIU Democracy Indexes for the period 2006-2018. ${ }^{9}$ The 2018 Index $^{10}$ assesses the existence

3 See V. Gienger, 2019. 'Will the Global March of Authoritarianism Turn Into a Stampede... or a Slog?'.Just Security, January 14. Retrieved 4 September 2019, https://www.justsecurity.org/ 62231/2019-global-march-authoritarianism-turn-stampede-slog/, with further references.

4 https://freedomhouse.org (retrieved 5 September 2019).

5 https://www.eiu.com (retrieved 5 September 2019).

6 Freedom House, 'Democracy in Retreat - Freedom in the World 2019'. Both the full and an abridged version of the report are available at https://freedomhouse.org/report/freedom -world/freedom-world-2019/democracy-in-retreat (retrieved 5 September 2019).

7 A. Forrest, 2019. 'Democracy Undergoing 'Alarming' Decline Around the World, Study Finds'. The Independent, February 5. Retrieved 5 September 2019. https://www.independent .co.uk/news/world/democracy-freedom-house-annual-report-civil-liberties-authoritarian-donald-trump-us-a8763196.html.

$8 \quad$ See page 13 of the full report $(\mathrm{n} 6)$.

9 The Index website displays the development of the average scores for each country from 2006 until 2018. Retrieved 6 September 2019, https://infographics.economist.com/2019/ DemocracyIndex/.

10 The Economist Intelligence Unit, 'Democracy Index 2018: Me Too? Political Participation, Protest and Democracy', 2019. The full version can be requested at https://www.eiu.com/ topic/democracy-index. A short summary is available at https://infographics.economist .com/2019/DemocracyIndex/ (retrieved 5 September 2019). 
and quality of democracy in 167 countries. On the basis of 60 indicators, it calculates for each country an average score from o to 10 . In 2018, the fully authoritarian regimes of North Korea, Syria, and the Democratic Republic of the Congo, got the worst scores, lower than 1.5. In the same year, the best scores above 9 - were achieved by the Scandinavian countries and New Zealand, Ireland, Canada, Australia, and Switzerland. The EU Member States were awarded scores ranking from 6.57 (Croatia) to 9.39 (Sweden).

The EIU Democracy Index divides the countries in four groups: authoritarian (scores 0-3.99), hybrid regimes (scores 4-5.99), flawed democracies (6-7.99), and full democracies (scores 8-10). The US was downgraded from full democracy to flawed democracy in 2016, after the first legal and political changes introduced by the Trump administration. Other countries that lost points and joined the inglorious category of "flawed democracies" at some point between 2006 and 2018 include Japan, Belgium, France, Greece, and Portugal. Even worse is the destiny of Italy, Cyprus, and the Eastern European Member States, which the Index has always considered flawed democracies during the whole period 2006-2018. Only two Southern European countries join the group of full democracies in the EIU's view: Malta (8.21) and Spain (8.08). The full democracies in Northern Europe include all Scandinavian countries and Ireland (scored higher than 9), the Netherlands, Luxemburg, Germany, and the UK (scored higher than 8.5), and Austria (8.29).

The Freedom in the World 2019 report and the latest EIU Democracy Index were published before Boris Johnson became Prime Minister. It is likely that the reports published in early 2020 will include critical sections about the UK, as the 2019 reports contain sections about the current attacks on democracy in the US and in various European countries.

The Freedom in the World reports and the Economist Intelligence Unit's Democracy Index can be seen as interesting examples of numeric comparative law, ${ }^{11}$ or more precisely: numeric comparative law-and-governance. ${ }^{12}$ The same is true for other qualitative and quantitative large-scale comparisons between countries performed by international or transnational actors (public

11 See M. Siems, 'Numerical Comparative Law: Do We Need Statistical Evidence in Law in Order to Reduce Complexity?' ${ }_{3}$ Cardozo Journal of International and Comparative Law 2005,521 .

12 From a socio-legal perspective, the indicators used in such large-scale comparisons between countries constitute a 'technology of global governance': K.E. Davis, B. Kingsbury, and S.E. Merry, 'Indicators as a Technology of Global Governance', Law and Society Review 46(1) (2012) 81. See also M. Infantino, 'Comparative Law in the Global Context: Exploring the Pluralism of Human Rights Indicators', European Journal of Comparative Law and Governance 2 (2015) 97 . 
or private) on the basis of data concerning law and governance. The perhaps most famous, and most controversial, example are the World Bank's Doing Business reports. ${ }^{13}$ Further examples include the UnEsco Culture for Development Indicators (CDIS), and the Sustainable Tourism Indicators published by the United Nations World Tourism Organization (UNWTO), commented on in a previous issue of this journal. ${ }^{14}$

Like the World Bank's Doing Business reports, also the Freedom in the World reports and the Economist Intelligence Unit's Democracy Index could be criticized for being possibly influenced by hidden biases of the experts who helped gathering the data. ${ }^{15}$ For example, from an Asian perspective, Peter Tasker sharply attacked the Economist Intelligence Unit's Democracy Index. ${ }^{16}$ He wrote: "How did the EIU come up with a scoring system that is supposedly accurate to two decimal places? What it did has the semblance of rigor. It asked various experts to answer 60 questions and assigned each reply a numerical value, with the weighted average deciding the ranking. Who are these experts? Nobody knows. (...) (D)espite the appearance of scientific objectivity, the whole exercise of ranking a country's democratic credentials is as much riddled with biases, value judgments and hidden agendas as awarding Oscars to films or Michelin stars to restaurants - which are also decided by groups of mysterious experts using criteria best known to themselves." He seems to suppose the existence of biases in favour of Scandinavian social models. ${ }^{17}$

I profoundly disagree with Tasker. Firstly, the concept of democracy underlying the EIU Index is well defined through 60 indicators grouped in five

13 See https://www.doingbusiness.org/ (retrieved 5 September 2019). The present Editorial shares the critical concerns of R. Michaels, 'Comparative Law by Numbers? Legal Origin Thesis, Doing Business Reports, and the Silence of Traditional Comparative Law', 57 American Journal of Comparative Law 2009, 765 with further references, as well as McCormack's recent critique of the evaluation of the quality of regulatory regimes according to the Doing Business indicators authored by G. McCormack, 'Why 'Doing Business' with the World Bank May be Bad for You', 19 European Business Organization Law Review 2018, 649 with further references.

14 P. Monaco, 'Cultural Heritage, Development, Tourism, and Global Indicators: The Experience of Western Balkan Countries', 5 European Journal of Comparative Law and Governance 2018, 89.

15 For an excellent scholarly criticism of the World Bank's Doing Business Reports see the two authors quoted in note 13 above.

16 P. Tasker, 'The Flawed 'Science' Behind Democracy Rankings', 2016. Nikkei Asian Review, February 25. Retrieved on 6 September 2019, https://asia.nikkei.com/NAR/Articles/Peter -Tasker-The-flawed-science-behind-democracy-rankings.

17 Ibid. 
categories: (1) electoral process and pluralism, (2) civil liberties, (3) the functioning of government, (4) political participation, and (5) political culture. The EIU very well explains the differences between its own methodology and the Freedom House's one, which only considers political freedoms and civil liberties. ${ }^{18}$ Secondly, the scores follow a combination of dichotomous and threepoint scoring system for the 60 indicators, in order to minimize the problems of comparability between the scores awarded by different experts. Thirdly, in addition to experts' assessments, the Index also uses public opinion surveys such as the World Values Survey, the Eurobarometer surveys, the Gallup polls, the Asian Barometer, the Latin American Barometer, the Afrobarometer and national surveys. ${ }^{19}$ Fourthly, the EIU has three seats: one in London, one in New York, and one in Hong Kong, which lets the hypothesis of hidden biases in favour of Scandinavian social models appear unfounded.

Anyway, the 2018 Index report itself honestly admits that definitions of democracy are contested, and that its methodology does not guarantee reliability but makes it more likely than less sophisticated scoring scales. ${ }^{20}$ This is perfectly understandable, since law and governance are not exact sciences.

\author{
Aurelia Colombi Ciacchi \\ Editor-in-Chief EJCL; Professor of Law and Governance, \\ University of Groningen, The Netherlands \\ a.l.b.colombi.ciacchi@rug.nl
}

\footnotetext{
18 See the full report of the 2018 EIU Democracy Index (n 10) 47 .

19 Ibid, $47-60$.

20 Ibid, 50.
} 